\title{
Editorial: Freshwater sustainability and aquatic ecology in a fast- changing world
}

Editorial: Ecologia e sustentabilidade de águas continentais em um mundo em rápida mudança

\author{
André Megali Amado ${ }^{1,2 *}$ (D), Rafael Marques Almeida ${ }^{3}$ (D), Simone Jaqueline Cardoso ${ }^{4}$ (D), \\ Joyce Andreia dos Santos 5 (D) and Antonio Fernando Monteiro Camargo ${ }^{6}$
}

\begin{abstract}
${ }^{1}$ Departamento de Biologia, Universidade Federal de Juiz de Fora - UFJF, Rua José Lourenço Kelmer, s/n, São Pedro, CEP 36036-900, Juiz de Fora, MG, Brasil

${ }^{2}$ Departamento de Oceanografia e Limnologia, Universidade Federal do Rio Grande do Norte UFRN, Avenida Gov. Silvio Pedroza, 1, Areia Preta, CEP 59014-100, Natal, RN, Brasil ${ }^{3}$ Department of Ecology and Evolutionary Biology, Cornell University, 14850, Ithaca, NY, USA

${ }^{4}$ Departamento de Zoologia, Universidade Federal de Juiz de Fora - UFJF, Rua José Lourenço Kelmer, s/n, São Pedro, CEP 36036-900, Juiz de Fora, MG, Brasil

${ }^{5}$ Programa de Pós-graduação em Biodiversidade e Conservação da Natureza, Universidade Federal de Juiz de Fora - UFJF, Rua José Lourenço Kelmer, s/n, São Pedro, CEP 36036-900, Juiz de Fora, MG, Brasil

${ }^{6}$ Departamento de Biodiversidade, Universidade Estadual Paulista - UNESP, Avenida 24/A, 1515, Bela Vista, CEP 13506-900, Rio Claro, SP, Brasil

*e-mail: andre.amado@ujf.edu.br
\end{abstract}

Cite as: Amado, A.M. et al. Freshwater sustainability and aquatic ecology in a fast-changing world. Acta Limnologica Brasiliensia, 2020, vol. 32, e100.

Humanity has been changing Earth's biosphere in unprecedented ways through planetary-scale impacts on geological and biological systems (Steffen et al., 2007; Paerl \& Huisman, 2009; Smith $\&$ Schindler, 2009). Because water is essential to life and environmental changes have been profoundly affecting the structure and functioning of aquatic ecosystems, it is critical to identify, understand, and find suitable solutions to the various aquatic sustainability issues of modern world.

This need has motivated us to edit two special topics where human impacts on aquatic ecosystems were addressed from several perspectives and scales. One special topic, "Opinions about aquatic ecology in a changing world - perspectives on contemporary issues", congregated 19 opinion and perspective papers, whereas the other, "Mini-reviews in Applied Limnology - causes, consequences and mitigation of human interventions in aquatic ecosystems", gathered seven review papers.

Contributed work addressed various issues, including effects of climate change on aquatic ecosystem dynamics, fish ecology and fisheries management, aquatic biodiversity conservation, human-caused impacts on freshwater ecosystems, water resources management, and aquatic ecotoxicology. The scale of the studies ranged from global to local, covering a broad spectrum of human-related subjects in freshwater systems in Brazil and several other American and European countries. Here we provide a broad synthesis of the variety of topics addressed in this collection of 26 papers published by Acta Limnologica Brasiliensia.

A few papers focused on ecological and biogeochemical processes on large scales. Cotner (2019) proposed that increased carbon dioxide 
$\left(\mathrm{CO}_{2}\right)$ in the atmosphere is contributing to excess carbon accumulation in biomass and subsequent ecosystem cycling, with probable consequences for whole-ecosystem metabolism. This phenomenon, referred to as "environmental obesity" by the author, could affect entire food webs, including human health by consumption of carbon-imbalanced food. In another global-scale perspective, Mullins \& Doyle (2019) pointed out that small lakes and ponds have an ecological importance that is disproportional to their reduced sizes. Small lakes and ponds provide valuable habitat for local species and are very active biogeochemical cycling spots. The authors call for special attention to human-made ponds to prevent eutrophication from spreading on landscape levels. Mullins \& Doyle (2019) contend that scientists should not neglect these small aquatic systems in global analyses and extrapolations. In a related review paper, Cardoso et al. (2019) discuss the role of aquatic sediments as sentinels of changes in aquatic and neighboring terrestrial ecosystems, reflecting key biogeochemical processes over time; the authors place a particular focus on the processing of carbon and contaminants.

Microbial ecology and ecotoxicology were the main emphasis of three papers. In a contribution focused on tropical freshwaters, M. Melo and H. Sarmento highlighted the importance of microbial communities as central to ecosystem processes. While microbes are recognized as fundamental to ecosystem functioning, playing central roles in biogeochemical cycling, they are largely understudied in tropical aquatic environments (Melo \& Sarmento, 2019). This lack of knowledge limits our ability to predict how microbial communities will respond to perturbations. Key players in microbial food webs whose ecology are even more understudied are aquatic viruses. Focusing primarily on Brazilian aquatic ecosystems, Junger et al. (2020) discussed the importance of aquatic viruses for nutrient cycling and top-down control of host populations. Finally, in a mini-review with an ecotoxicological focus, Vilas-Boas et al. (2020) showed the role of ciliates in aquatic ecosystems, including the advantages of using them as model organisms in ecotoxicological studies.

Discussion on biodiversity conservation, ranging from country to regional scales, was targeted in some papers. Celi \& Villamarín (2020) provided a general perspective on current and historical pressures, including oil extraction, mining, agriculture, and dams, on biodiversity of freshwater ecosystems in Ecuador - the world's country with the largest number of species per unit area. A regional-scale viewpoint was presented by Biesboer (2019) regarding the wild rice Zizania palustris $L$. in Minnesota (Northern U.S.A). The wild rice is a vital wetland plant connected to native North Americans who have historically used it for subsistence and trade. However, wild rice is also economically crucial for large-scale commercial agriculture. Thus, the genetic diversity of wild rice in natural populations has been threatened by large plantations. Wild rice cultivation currently faces necessary trade-offs between conservation and economics.

In addition to the direct impacts of human activities, indirect effects via global climate change also jeopardize biologically diverse aquatic ecosystems. This is true for Pantanal, Earth's largest wetland. Focusing on Northern Pantanal, Lázaro et al. (2020) discussed the consequences of an increase in the number of dry days over a timeseries of 42 years. According to them, the Northern Pantanal had an increase in 13\% of dry days and a loss in the water mass of about $16 \%$ considering the past 10 years. Less rain in the region causes conversion from floodplain to nonflooded land, decreases river depth, and poses risks to floodplain ecosystem services as a whole. This timely contribution was anecdotally confirmed in the current year of 2020, when the Pantanal has been suffering a record-breaking drought and consequently a massive destruction due to uncontrolled fire.

The setting of aquatic environments in Brazil extends beyond natural systems such as the Pantanal. Brazil's freshwater reserve is immense and thousands of man-made lakes exist throughout the country. Many more reservoirs may be built in the future, including large projects in biodiversity hotspots (Almeida et al., 2019). Prior to impoundment, Brazilian law requires the removal of terrestrial vegetation within the flooded area of reservoirs. However, Tonella et al. (2020) argue that the law mandating removal of vegetation, enacted in the 1960s, is outdated and often misinterpreted, since the flooded trunks promote positive feedback to fish production. The authors call for a revision of the legislation in order to incorporate important scientific advancements in fish ecology and fisheries science over the last few decades.

Fishes play key ecosystem roles and are important sources of animal food globally. As fish biodiversity loss accelerates worldwide, fish conservation has been receiving increasing attention. Angelini (2019) 
pointed out that aquatic food webs are being disrupted by a myriad of threats, with consequences for fisheries production. In particular, the author contends that the continued fragmentation of rivers by dams is problematic for freshwater food web rewiring, because it impedes longitudinal movements of large mobile generalist fish species that are central for the re-colonization of areas with disrupted food webs. Furthermore, fish conservation efforts must encompass all scales of study and life history stages. Accordingly, conservation of fish eggs and larvae is fundamental for the maintenance of fishery resources. In a paper focused on the Brazilian Amazon, Zacardi et al. (2020) review the current knowledge on the ecology of early life stages of Amazon fish, discussing how increasing knowledge of ichthyoplankton ecology can support management strategies aimed at mitigating disturbances across the basin.

It is important to point out that fish conservation effectiveness relies on integrated evaluations, since fish ecology dynamics are complex and dependent on interactions at the population and community levels. In this regard, two articles discuss the ecological effects of non-native fish species on native and endemic fish assemblages in Brazil (Garcia et al., 2019; Camargo \& Amorim, 2020). In addition to concerns about the introduction of species, Garcia et al. (2019) discuss the deleterious effects of introducing fish parasites, which would not occur under natural conditions, and how this introduction can directly affect native fish fauna. Likewise, it is worrisome how the production of exotic fish species can cause environmental damage such as eutrophication (Henry-Silva et al., 2019; Camargo \& Amorim, 2020). In two related opinion pieces, Camargo \& Amorim (2020) contend that fish farming in cages should be restricted in Brazil, whereas Henry-Silva et al. (2019) discuss practices and conditions that can affect the sustainability of fish farming in cages of reservoirs in Brazil's semiarid region. Finally, running counter to these papers on non-native species, Santana et al. (2020) discuss how the engagement of local human communities in sustainable management plans can balance capture and conservation of ecologically, culturally, and economically important fish's species such as the pirarucu (Arapaima gigas).

Understanding the multiple dimensions of aquatic ecosystems and finding ways to manage water resources minimizing environmental damage is urgent. In both special research topics, we received several contributions addressing water pollution and water resources management-one of the greatest sustainability challenges of our time. Quadra et al. (2019) presented a broad overview of many human-related pollutants in aquatic ecosystems, including eutrophication-causing nutrients, organic compounds, heavy metals, pesticides, and novel synthetic chemicals. In a related review, Loureiro \& Hepp (2020) highlighted that phytoremediation is as an option to reduce trace element contamination in streams. Sobek \& Undeman (2019) discuss another critical issue in water resources management: the need to incorporate integrated approaches that can detect and comprehend the effects of a wide range of novel synthetic chemicals that are being increasingly detected in aquatic ecosystems. In a related contribution about emerging pollution, Resende et al. (2020) discuss the role of aquatic environments within the "One Health" context. Under poor management, aquatic ecosystems could transport and accumulate anthropogenic residues, ultimately contributing to the emergence of antibiotic-resistant bacteria. As antimicrobial substances vary in their degradation characteristics, strategies to remove them from the water should be designed at the individual level. Worryingly, however, in many parts of the world-especially in low- and middle-income countries-wastewater treatment infrastructure is obsolete or even absent. Facing limited financial resources and scarce information on the underlying ecological conditions of downstream water bodies, resource managers and policy makers are often forced to design watershed management strategies without knowing their real effectiveness. Capps (2019) discusses the ecology and management of freshwater systems, with emphasis on how mismatches between the governance of wastewater management and watershed ecology may exacerbate environmental problems.

Problems associated with water quality deterioration are often exacerbated by the degradation of ecological buffers. This is true for Brazil, where recent modifications in the Native Vegetation Protection Law has threatened entire ecosystems by reducing riparian protected areas. Feijó-Lima et al. (2019) showed that changes in terrestrial canopy cover in Atlantic Rainforest streams are related to significant changes in chlorophyll-a concentrations and invertebrate functional groups, with loss of ecosystem functions. Since rivers are affected by processes occurring in terrestrial environments of the watershed, such impacts can propagate longitudinally downstream 
(Feijó-Lima et al., 2019). Likewise, groundwater degradation is also a current issue. Hirata \& Suhogusoff (2019) highlighted that aquifers have remarkable functions in the hydrological cycle, regulating the perenniality of rivers and lakes and preserving mangroves, marshes, and vegetation in dry periods. However, there has been a growing increase in groundwater contamination with anthropic compounds such as chlorinated organic solvents, heavy metals, and nitrate. The authors emphasize that the loss of groundwater quality is often induced by the lack of control in groundwater extractions nationwide, which brings intrusion of saline or low-quality water into aquifers; poor design, construction and maintenance of supply wells are also culprits.

The diversity of environmental problems faced nowadays is complex and a multitude of actions are needed in order to achieve feasible solutions. Ecological monitoring is one example, and this is especially true for cyanobacterial harmful algal blooms. In this regard, I. Ogashawara provides a perspective on the use of remote sensing to monitor harmful algal blooms, with a focus on recent advancements, lingering limitations, and challenges (Ogashawara, 2019). Extending beyond monitoring, Ribas et al. (2019) explain how challenging it is to identify causal relationships between interventions and aquatic ecosystem responses. They argue that limnologists still fail in identifying causal relationships, mainly when estimating the impacts of interventions, which cannot be addressed by simply using models that relate predictor and response variables. Relatedly, $\mathrm{R}$. Bozelli showed a perspective about the challenges of restoring tropical freshwater ecosystems. Despite investments that usually accompany aquatic restoration projects, the spatial aspects of ecosystem recovery are still poorly understood. For instance, remediation actions for environmental impacts are rarely implemented in large scales such as the watershed, with priority actions being local and selected based on environmental, economic, political, and, social factors. The author also proposes an integrated environmental management that involves the rational use and protection of aquatic ecosystems beyond their boundaries (Bozelli, 2019).

The 26 articles published in both special research topics cover several aspects of freshwater degradation, impact evaluation, management, restoration, and how human activities affect water quality and services. This diverse set of papers reveals the high complexity and large breadth of approaches for dealing with water issues, from microorganisms to large fishes, from small ponds to landscape levels on a global scale, from introduction of toxic compounds to introduction of exotic species, and from confronting obsolete legislations to proposition of new scientific paradigms. We hope that this robust sample of water challenges to current and future human society supports broad discussion fundamental to democracy. We are positive that interdisciplinary knowledge in aquatic sciences is foundational to integrate social, economic, and environmental dimensions and thus minimize negative consequences of human development to aquatic ecosystems functioning and integrity.

\section{Acknowledgements}

We are thankful to the several authors and reviewers that timely contributed to these special research topics. We are also thankful to R. Angelini for contributions and reviewing this editorial. AMA and AFMC gratefully acknowledge continuous funding through Research Productivity Grants provided by CNPq (Processes 310033/2017-9 and 309478/2017-0).

\section{References}

ALMEIDA, R.M., SHI, Q., GOMES-SELMAN, J.M., WU, X., XUE, Y., ANGARITA, H., BARROS, N., FORSBERG, B.R., GARCÍA-VILLACORTA, R., HAMILTON, S.K., MELACK, J.M., MONTOYA, M., PEREZ, G., SETHI, S.A., GOMES, C.P. and FLECKER, A.S. Reducing greenhouse gas emissions of Amazon hydropower with strategic dam planning. Nature Communications, 2019, 10(1), 4281. http://dx.doi.org/10.1038/s41467-019-12179-5. PMid:31537792.

ANGELINI, R. Aquatic food webs will need to stand on giants shoulders. Acta Limnologica Brasiliensia, 2019, 31, e108. http://dx.doi.org/10.1590/s2179$975 \times 5019$.

BIESBOER, D.D. The ecology and conservation of wild rice, Zizania palustris L., in North America. Acta Limnologica Brasiliensia, 2019, 31, e102. http:// dx.doi.org/10.1590/s2179-975x2319.

BOZELLI, R.L. The challenge of restoring tropical freshwater ecosystems. Acta Limnologica Brasiliensia, 2019, 31, e110. http://dx.doi.org/10.1590/s2179$975 \times 4619$.

CAMARGO, A.F.M. and AMORIM, R.V. Fish farming in cages: a practice to be restricted in Brazil. Acta Limnologica Brasiliensia, 2020, 32, e101. http:// dx.doi.org/10.1590/s2179-975x5519. 
CAPPS, K.A. Wastewater infrastructure and the ecology and management of freshwater systems. Acta Limnologica Brasiliensia, 2019, 31, e104. http:// dx.doi.org/10.1590/s2179-975x3719.

CARDOSO, S.J., QUADRA, G.R., RESENDE, N.D.S. and ROLAND, F. The role of sediments in the carbon and pollutant cycles in aquatic ecosystems. Acta Limnologica Brasiliensia, 2019, 31, e201. http:// dx.doi.org/10.1590/s2179-975x8918.

CELI, J.E. and VILLAMARÍN, F. Freshwater ecosystems of Mainland Ecuador: diversity, issues and perspectives. Acta Limnologica Brasiliensia, forthcoming 2020, 32 .

COTNER, J.B. How increased atmospheric carbon dioxide and 'The Law of the Minimum' are contributing to environmental obesity. Acta Limnologica Brasiliensia, 2019, 31, e113. http:// dx.doi.org/10.1590/s2179-975x6519.

FEIJÓ-LIMA, R., ZANDONÀ, E., SILVA, B.S.D., TROMBONI, F., MOULTON, T.P. and THOMAS, S.A. Longitudinal dimensions of land-use impacts in riverine ecosystems. Acta Limnologica Brasiliensia, 2019, 31, e107. http://dx.doi.org/10.1590/s2179$975 \times 4519$.

GARCIA, D.A.Z., ORSI, M.L. and SILVA-SOUZA, Â.T. From Africa to Brazil: detection of African Oreochromis niloticus parasites in Brazilian fish farms. Acta Limnologica Brasiliensia, 2019, 31, e202. http:// dx.doi.org/10.1590/s2179-975x6218.

HENRY-SILVA, G.G., MELO-JUNIOR, H.D.N. and ATTAYDE, J.L. Extreme drought events and the sustainability of fish farming in net cages in reservoirs of the semi-arid northeastern region in Brazil. Acta Limnologica Brasiliensia, 2019, 31, e112. http:// dx.doi.org/10.1590/s2179-975x7519.

HIRATA, R. and SUHOGUSOFF, A.V. How much do we know about the groundwater quality and its impact on Brazilian society today? Acta Limnologica Brasiliensia, 2019, 31, e109. http:// dx.doi.org/10.1590/s2179-975x4419.

JUNGER, P.C., ALMEIDA, R.M., MENDONÇA, R., FARJALLA, V.F., MELO, R.C.N.D., ROLAND, F. and BARROS, N. Not all viruses in nature are human enemies: a perspective on aquatic virus ecology in Brazil. Acta Limnologica Brasiliensia, 2020, 32, e105. http://dx.doi.org/10.1590/s2179-975x3720.

LÁZARO, W.L., OLIVEIRA-JÚNIOR, E.S., SILVA, C.J.D., CASTRILLON, S.K.I. and MUNIZ, C.C. Climate change reflected in one of the largest wetlands in the world: an overview of the Northern Pantanal water regime. Acta Limnologica Brasiliensia, 2020, 32, e104. http://dx.doi.org/10.1590/s2179$975 \times 7619$.

LOUREIRO, R.C. and HEPP, L.U. Stream contamination by trace elements: biota incorporation and phytoremediation. Acta Limnologica Brasiliensia,
2020, 32, e201. http://dx.doi.org/10.1590/s2179$975 \times 2219$.

MELO, M.L.D. and SARMENTO, H. Anthropogenic impacts on aquatic bacteria: a perspective from the tropics. Acta Limnologica Brasiliensia, 2019, 31, e111. http://dx.doi.org/10.1590/s2179-975x4919.

MULLINS, M.L. and DOYLE, R.D. Big things come in small packages: why limnologists should care about small ponds. Acta Limnologica Brasiliensia, 2019, 31, e105. http://dx.doi.org/10.1590/s2179-975x4119.

OGASHAWARA, I. Advances and limitations of using satellites to monitor cyanobacterial harmful algal blooms. Acta Limnologica Brasiliensia, 2019, 31, e103. http://dx.doi.org/10.1590/s2179-975x0619.

PAERL, H.W. and HUISMAN, J. Climate change: a catalyst for global expansion of harmful cyanobacterial blooms. Environmental Microbiology Reports, 2009, 1(1), 27-37. http://dx.doi.org/10.1111/j.17582229.2008.00004.x. PMid:23765717.

QUADRA, G.R., TEIXEIRA, J.R.P.V.A., BARROS, N., ROLAND, F. and AMADO, A.M. Water pollution: one of the main Limnology challenges in the Anthropocene. Acta Limnologica Brasiliensia, 2019, 31, e203. http://dx.doi.org/10.1590/s2179$975 \times 5118$.

RESENDE, J.A., SILVA, V. L. and DINIZ, C.G. Aquatic environments in the One Health context: modulating the antimicrobial resistance phenomenon. Acta Limnologica Brasiliensia, 2020, 32, e102. http:// dx.doi.org/10.1590/s2179-975x4719.

RIBAS, L.G.D.S., PADIAL, A.A. and BINI, L.M. Advancing impact evaluation in applied limnology. Acta Limnologica Brasiliensia, 2019, 31, e101. http:// dx.doi.org/10.1590/s2179-975x2119.

SANTANA, E.A., OLIVEIRA, E.F.D., BALBINO, N.D.S. and GURGEL, H. Management of Pirarucu (Arapaima gigas, Teleostei, Osteoglossidae) in sustainable use units as a proposal for the restoration of aquatic ecosystems. Acta Limnologica Brasiliensia, 2020, 32, e204. http://dx.doi.org/10.1590/s2179$975 \times 2019$.

SMITH, V.H. and SCHINDLER, D.W. Eutrophication science: where do we go from here? Trends in Ecology \& Evolution, 2009, 24(4), 201-207. http://dx.doi. org/10.1016/j.tree.2008.11.009. PMid:19246117.

SOBEK, A. and UNDEMAN, E. Tunnel vision in current chemicals management cannot deal with the unknown risk of synthetic chemicals in aquatic systems. Acta Limnologica Brasiliensia, 2019, 31, e106. http://dx.doi.org/10.1590/s2179-975x4219.

STEFFEN, W., CRUTZEN, P.J. and MCNEILL, J.R. The Anthropocene: are humans now overwhelming the great forces of nature? Ambio, 2007, 36(8), 614-621. http://dx.doi.org/10.1579/00447447(2007)36[614:TAAHNO]2.0.CO;2. PMid:18240674. 
TONELLA, L.H., VITORINO JUNIOR, O.B., LIMA-JUNIOR, D.P., GOMES, L.C., PELICICE, F.M. and AGOSTINHO, A.A. Extemporaneous environmental legislation: an analysis of the conflicts underlying Law 3824/1960 on coarse wood removal in Brazilian artificial reservoirs. Acta Limnologica Brasiliensia, 2020, 32, e103. http:// dx.doi.org/10.1590/s2179-975x9019.

VILAS-BOAS, J.A., SENRA, M.V.X. and DIAS, R.J.P. Ciliates in ecotoxicological studies: a minireview. Acta Limnologica Brasiliensia, 2020, 32, e202.
ZACARDI, D.M., SANTOS, J.A.D., OLIVEIRA, L.S.D., CAJADO, R.A. and POMPEU, P.S. Ichthyoplankton studies as referential for the management and monitoring of fishery resources in the Brazilian Amazon basin. Acta Limnologica Brasiliensia, 2020, 32, e203. http://dx.doi. org/10.1590/s2179-975x6619.

Editor Associado: Ronaldo Angelini

Received: 17th September 2020 Accepted: 15th October 2020 


\section{Acta Limnologica Brasiliensia}

\section{Erratum}

In the article "Editorial: Freshwater sustainability and aquatic ecology in a fast-changing world", DOI: http://dx.doi.org/10.1590/s2179-975x10020020, published in Acta Limnologica Brasiliensia, 2020, vol. 32, e100:

Where it reads:

"A regional-scale viewpoint was presented by Biesboer (2019) regarding the wild rice Zizania palustris L. in Minnesota (Northern U.S.A). The wild rice is a vital wetland plant connected to native North Americans who have historically used it for subsistence and trade. However, wild rice is also economically crucial for large-scale commercial agriculture. Thus, the genetic diversity of wild rice in natural populations has been threatened by large plantations. Wild rice cultivation currently faces necessary trade-offs between conservation and economics.".

It should be read:

"A regional-scale viewpoint was presented by Biesboer (2019) regarding the wild rice Zizania palustris L. in Minnesota (Northern U.S.A). The wild rice is a vital wetland plant connected to native North Americans who have historically used it for subsistence and trade. Wild rice is also economically crucial for large-scale commercial agriculture. The author discusses the conservation and threats to this wild rice species and provides a list of potential conservation actions and challenges.". 